\title{
Development of Guided Inquiry Based Student Worksheet for First College Student
}

\author{
Hidayati Kardena*, Mawardi Mawardi ${ }^{* *}$ \\ * Postgraduate Program on Chemistry Education, Universitas Negeri Padang \\ ${ }^{* *}$ Chemistry Lecturer, Universitas Negeri Padang \\ DOI: 10.29322/IJSRP.10.10.2020.p10650 \\ http://dx.doi.org/10.29322/IJSRP.10.10.2020.p10650
}

\begin{abstract}
This study aims to produce a worksheet of chemical equilibrium which based on guided inquiry in order to measure the validity, practicality of the worksheet. This worksheet is structured using a guided inquiry model and is equipped with multiple representations. This research method is a research development using the Plomp model. The research subjects were students majoring in chemistry in 2019. The research instruments used were validation sheets and practicality sheets. This worksheet is validated by 4 validators consisting of chemistry lecturers and the practicality test (field test) was conducted by 45 students majoring in Chemistry, Universitas Negeri Padang. This research found that the students' worksheets have a very high level of validity $(v=0,88)$ and very high level of practicality by students $(\mathrm{k}=0,87)$ and high by the lecturer $(\mathrm{k}=0,79)$.
\end{abstract}

Index Terms- guided inquiry, chemical equilibrium, student worksheet, multiple representations

\section{INTRODUCTION}

Chemistry is a part of natural science that requires direct observation in the learning process. Direct observation is needed because chemistry studies about the nature, structure, structure and changes in matter and energy that accompany these changes. Basically chemistry studies about topics that are mostly abstract and require understanding at the molecular or sub microscopic level [1]. People's understanding of chemistry can be seen through its ability to transfer and connect macroscopic, submiscroscopic, and symbolic phenomena [2]. In addition, designate one author as the "corresponding author". The macroscopic level is a chemical representation obtained through real observations of a phenomenon that can be seen and felt by the five senses [3]. The submicroscopic level is a chemical representation that explains and provides an understanding of the structure and processes at the particle (atom / molecular) level of the observed macroscopic phenomena [4]. Symbolic representations, namely qualitative and quantitative representations of chemistry, namely chemical formulas, diagrams, calculations and reaction equations.

Chemical equilibrium is an important material that is difficult to study because it relates to chemical reactions, where chemical equilibrium answers the question of how far a chemical reaction can go [5]. Chemical equilibrium is one of the most difficult concepts in chemistry for students to learn at various levels [6] either in middle school or in college [7]. Chemical equilibrium is a material that students must study in basic chemistry courses for first college sudent majoring ing Chemistry.

To increase activeness in learning chemistry, namely chemical equilibrium material in class, a quality learning device is needed in the form of teaching materials that are arranged using a learning model that is in accordance with that material [8]. One of the teaching materials that can be used in helping the learning process is student worksheets (LKM). LKM is expected to increase understanding of concepts, attract interest in learning and help students actively involved in the learning process. Worksheets are arranged systematically with an emphasis on certain aspects so that the skills of students in the learning process can be obtained [9]. Worksheets are arranged with a learning model that contains activity stages that guide students to maximize understanding of the concepts being studied.

One of the learning models that can increase student activity is guided inquiry. In guided inquiry, students will be actively involved during the learning process. The guided inquiry learning cycle is divided into 5 stages, namely orientation, exploration, concept formation, application and closure [10]. Research conducted by Parappiliy et al (2013) shows that student performance increases when using the inquiry learning model so that it provides good results on learning outcomes [11]. This student worksheet that will be developed uses a guided inquiry model and is equipped with multiple representations consisting of three levels namely macroscopic, submicroscopic and symbolic This study aims to produce a guided inquiry based student worksheet of chemical equilibrium and to see the validity and practicality of the worksheet.

\section{RESEARCH METHODS}

\subsection{Research Design}

This research used the type of Research and Development ( $R \& D)$. The research method used in this study is Plomp model. Based on the Plomp development cycle, the Plomp model is divided into three phases, the first stage is preliminary research, the second stage is 
the development or prototyping phase, and the third stage is assessment phase [12]. Formative evaluation research design use in this study can be seen in figure 1.

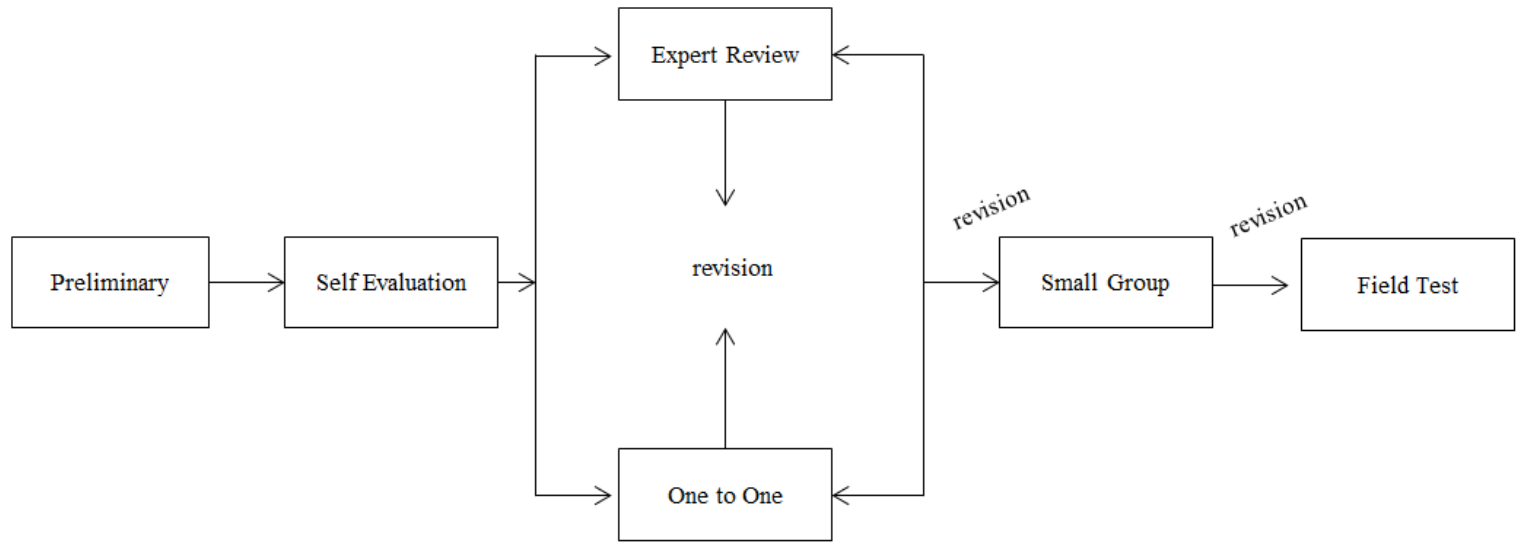

\subsection{Research Subject}

Figure 1. Formative evaluation research design

The subjects in this study were chemistry lecturers as validators of student worksheets and as practical subjects and 45 students of Universitas Negeri Padang majoring in chemistry in 2019.

\subsection{Data Collection}

a. Validity Analyisis

The validator's assessment of each statement was analyzed using Aiken's V formula. The formula proposed by Aiken is as follows [13] :

$$
\begin{aligned}
& \mathrm{V}=\sum \mathrm{s} /[\mathrm{n}(\mathrm{c}-1)] \\
& \mathrm{S}=\mathrm{r}-\mathrm{lo}
\end{aligned}
$$

Information :

Lo $=$ the lowest number of validity assessments (for example 1)

$\mathrm{C}=$ the highest number of validity assessments (eg 4)

$\mathrm{R}=$ number given by the assessor

$\mathrm{N}=$ number of evaluators

b. Practicality Analysis

Data analysis techniques for validity and practicality based on a questionnaire from lecturers and students using the kappa kohen (k) formula [14] :

$$
k=\frac{P o-P e}{1-P e}
$$

Information :

$\mathrm{k}$ = kappa moment value

$\mathrm{Po}=$ realized proportion

$\mathrm{Pe}=$ proportion not realized

The level of validity and practicality of the guided inquiry-based student worksheet will be seen after being converted to the categories in Table 1.

Table 1. Validity and practicality level categories

\begin{tabular}{cc}
\hline K value & Category \\
\hline $0,81-1,00$ & Very high \\
$0,61-0,80$ & High \\
$0,41-0,60$ & Medium \\
$0,21-0,40$ & Low \\
$0,00-0,20$ & Very low \\
$<0,00$ & Invalid \\
\hline
\end{tabular}

\section{RESULT AND DISCUSSION}

\subsection{Preliminary Research}

In this stage, the identification and analysis needed to develop research to develop a chemical equilibrium worksheet based on guided inquiry is carried out. Four analyzes were carried out, namely needs analysis, curriculum analysis, student analysis and concept analysis. Based on the analysis conducted, it can be concluded that there is no teaching material in the form of student worksheets so 
that this teaching material can be developed. Furthermore, the material contained in the student worksheet to be developed has been adjusted to the syllabus of basic chemistry courses at the university. After this analysis has been completed, the next step is to design a student worksheet based on guided inquiry chemistry.

\subsection{Prototyping Phase}

In the prototyping phase of making this prototype, a formative evaluation was carried out. Formative evaluation is carried out in each prototype produced. Prototyping Phase produces prototype 1, prototype 2, and prototype 3 which is the result of formative evaluation. Formative evaluation was conducted based on Tessmer's formative evaluation. Tessmer's formative evaluation includes four stages, namely: self-evaluation; expert review and one-to-one evaluation; small group evaluation test; and field test.

a. Prototype 1

After formulating goals based on the Basic Chemistry syllabus, development activities were continued by designing a Student Worksheet (LKM) for Chemical Equilibrium based on Guided Inquiry. LKM components designed are cover, foreword, table of contents, list of pictures, characteristics of LKM, instructions for use of LKM, Expected Learning Outcome (ELO) for Chemistry Education Study Program, expected final abilities, study materials (teaching materials), learning objectives , concept maps, activity sheets, worksheets, and references.

b. Prototype 2

After producing prototype 1 in the form of an initial design, then at this stage a formative evaluation was carried out in the form of self-evaluation. Self-evaluation is carried out by means of a check list system of the important parts that must be included in student worksheets. based on the results of this evaluation, the compiled student worksheets already have components that must be included in the LKM so there is no revision in this evaluation.

c. Prototype 3

Prototype 3 resulted from expert review and one-to-one evaluation of prototype 2. Prototype 2 was validated by chemistry lecturers and one-one evaluation was carried out by 3 chemistry students. The validation sheet contains 26 aspects of the assessment consisting of a content component, a construction component, a language component, and a graphic component. The evaluation data for the guided inquiry-based LKM validation sheet were then analyzed using the Aiken's V formula. The results of the validation of four lecturers on this student worksheet can be seen in Figure 2

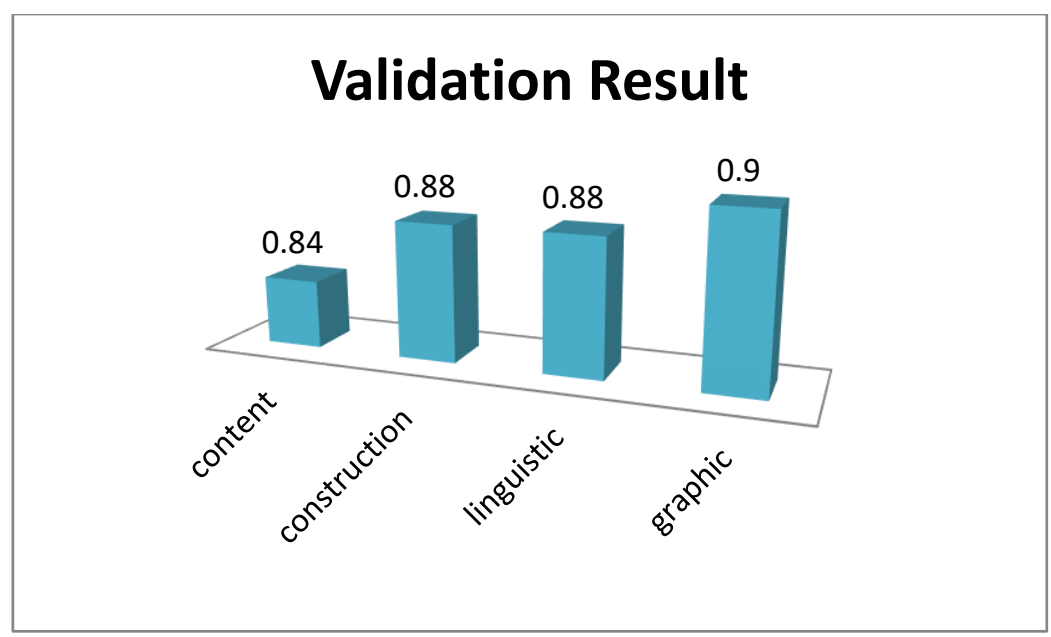

Figure 2. Average validation results of student worksheets

Overall the average validation from experts has a value of $\mathrm{v}=0.88$ which is included in the very high category. The results of the LKM validation show that the LKM developed is valid. After validation then a one-to-one evaluation was carried out on chemistry students at Padang State University. This evaluation was carried out aimed at seeing student responses to the prototype 2 that had been produced. The students who were used as the test subjects consisted of three people. Data obtained from interview sheets given to students. The results of the interview found that in terms of cover design and color selection makes students interested in learning it and the use of the language is easily understood. After validating and evaluating one to one, the revision results are prototype 3 .

d. Prototype 4

To produce prototype 4, a small group evaluation test was carried out on prototype 3. Small group evaluation was carried out on 6 students majoring in chemistry. This evaluation is obtained through a questionnaire distributed to students. The practical results of small group evaluation can be seen in table 2 . 
Table 2. Results of student response questionnaire on small group evaluation

\begin{tabular}{cccc}
\hline No & Aspect & $\mathrm{k}$ & Category \\
\hline 1 & Ease of Use & 0,86 & Very practical \\
2 & Time efficiency & 0,80 & Very practical \\
3 & The benefits & 0,81 & Very practical \\
\hline & Average & 0,82 & Very practical \\
\hline
\end{tabular}

\subsection{Assesment Phase}

At this stage, a field test is carried out to get the practical level of the worksheets that have been produced. Field tests were carried out on 2 chemistry lecturers and 45 students. The results of the questionnaire analysis given to lecturers and students can be seen in table 3 and table 4.

Table 3. Results of student response questionnaires

\begin{tabular}{cccc}
\hline No & Aspect & $\mathrm{k}$ & Category \\
\hline 1 & Ease of Use & 0,87 & Very practical \\
2 & Time efficiency & 0,85 & Very practical \\
3 & The benefits & 0,86 & Very practical \\
\hline & Average & 0,82 & Very practical \\
\hline
\end{tabular}

Table 4. Results of lecturer response questionnaires

\begin{tabular}{cccc}
\hline No & Aspect & $\mathrm{k}$ & Category \\
\hline 1 & Ease of Use & 0,83 & Very practical \\
2 & Time efficiency & 0,76 & Practical \\
3 & The benefits & 0,77 & Practical \\
\hline & Average & 0,79 & Practical \\
\hline
\end{tabular}

Based on table 4 the practicality of the field test obtained a kappa moment of 0.82 with a very high practicality category. This shows that the compiled worksheets are practically used by students both in terms of ease of use, time efficiency, and the benefits. This shows that practicality considerations can be seen from the aspects of ease of use, time efficiency, and benefits [15]. Based on table 5 shows that the practicality of the field test based on the lecturer response questionnaire has a kappa moment value of 0.79 in the high category. The results of practicality show that the LKM developed has been practically used in the learning process.

\section{CONCLUSION}

Based on the research results, the student worksheets that have been developed have a very high validity category with a value of $\mathrm{v}$ 0,88 . the results of the evaluation of the small group carried out have a kappa moment value of 0,82 which is very high category, while the practicality test on the field test had an average kappa moment value of 0,87 from the student response questionnaire with the very high practicality category and 0,79 from the lecturer response questionnaire with the high practicality category.

\section{REFERENCES}

[1] Mawardi., Irham, M.S, and Oktavia,B. (2017). The Development of Guided Inquiry-based Worksheet on Colligative Properties of Solution for Chemistry Learning. Advances in Social Science, Education and Humanities Research (ASSEHR), 57(1) : 38 - 42.

[2] Sunyono. 2014. Model Pembelajaran Kimia Berbasis Multiple Representasi dalam Membangun Model Mental Mahasiswa pada Mata Kuliah Kimia Dasar. [Disertasi]. Surabaya: Universitas Negeri Surabaya.

[3] Talanguer, Vicente. 2010. "macro, submicro, and symbolic: the many faces of the chemistry "triplet". International journal of science education. Januari 2010. Vol.33 No.2 Hal 179-195.

[4] Sirhan, Ghassan. 2007. "Learning Difficulties in Chemistry". International Journal of Science Education. September 2007. Vol.4 No.2 Hal 2-19.

[5] McMurry, John E and Robert C. Fay. 2003. Chemistry 4th Edition. USA: Pearson Prentice Hall.

[6] Chiu, M.H., Chou, C.C., \& Liu, C.J. (2002). Dynamic Processes of Conceptual Change : Analysis of Constructing Mental Models of Chemical Equilibrium. Journal of Research in Science Teaching. 39 (8), hlm 688-712

[7] Van Driel, J. H., \& Graber, W. 2002. The Teaching and Learning of Chemical Equilibrum. Chemical Education. 271-281.

[8] Deliana, Rini. 2018. Pengembangan Bahan Ajar Terintegrasi Lembar Kerja Mahasiswa Berbasis Inkuiri Terbimbing pada Materi Kesetimbangan Kimia [tesis]. Medan : Universitas Negeri Medan

[9] Choo, S.S.Y., Rotgans, J.I., Yew, F.H.J. \& Schmidt, H.G. (2011). Effect of Worksheet Scaffods on Student Learning in Problem Based Learning . Jurnal Adv in Health Sci Educ of Singapure, 16(1) : $517-528$.

[10] Hanson D., M. 2007. Designing Process-Oriented Guided-Inquiry Activities. In Faculty Guidedbook: A Comprehensive Tool For Improving Faculty Performance, ed. S. W. Beyerlein and D. K. Apple. Lisle, IL: Pacific Crest.

[11] Parappilly, M. (2013). An Inquiry-Based Approach to Laboratory Experiences: Investigating Students' Ways of Active Learning, International Journal of Innovation in Science and Mathematics Education, 21(5): $42-53$.

[12] Plomp T (SLO) and Nieveen N (SLO) 2013 Educational Design Research Educational Design Research Educ. Des. Res.

[13] Azwar, S. 2012. Reliabiltas dan Validitas. Edisi 4. Yogyakarta : Pustaka Pelajar. 
[14] Boslaugh S 2008 Statistics In A Nutshell Desktop Quick Reference (Beijing, Cambridge, Famham, Köln, Sebastopol, Taipei, Tokyo: O'reilly).

[15] Sukardi H. M. 2011. Evaluasi Pendidikan: Prinsip dan Operasionalnya. Jakarta: Bumi Aksara.

\section{AUTHORS}

First Author - Hidayati Kardena, Postgraduate Program on Chemistry Education , Universitas Negeri Padang, hkardena@gmail.com Second Author - Mawardi, Chemistry Lecturer, Universitas Negeri Padang, mawardianwar@ fmipa.unp.ac.id . 